\title{
Monitoring Thermal Treatments Applied to Meat Using Traditional Methods and Spectroscopic Techniques: a Review of Advances over the Last Decade
}

\author{
Abdo Hassoun $^{1}$ (D) - Abderrahmane Aït-Kaddour ${ }^{2}$ - Amna Sahar ${ }^{3,4}$ - Daniel Cozzolino ${ }^{5}$
}

Received: 15 May 2020 / Accepted: 2 August 2020 / Published online: 24 August 2020

(C) The Author(s) 2020

\begin{abstract}
Thermal treatments are often applied during processing or preparation of muscle foods aiming to both improve the palatability and organoleptic properties and to ensure the safety of the treated food. However, the application of inappropriate or severe thermal treatments can lead to undesirable changes in the sensory and nutritional quality of heat-processed products, and especially so for foods that are sensitive to thermal treatments, such as meat and meat products. The impact of traditional and new heat processing technologies (e.g. microwaving, ohmic, and radio frequency heating) on meat quality has been widely assessed by a wide range of conventional methods, such as sensory, microbiological, and physicochemical methods. Due to the destructive nature and the time required to perform these assessments, alternative online methods are highly needed in order to achieve continuous monitoring through online applications. In this review paper, both traditional and new heat processing methods and their impact on the quality of meat will be first briefly presented. The methods and techniques that have been applied to monitor changes induced by application of thermal treatments will be then discussed. The main focus will be put on the application of spectroscopic techniques, as rapid and non-destructive methods compared to most conventional techniques. Finally, future trends and possible applications and research directions will be suggested.
\end{abstract}

Keywords Spectroscopy $\cdot$ Heat $\cdot$ Quality $\cdot$ Processing $\cdot$ Analysis $\cdot$ Pork $\cdot$ Beef

Abdo Hassoun

abdo.hassoun@nofima.no

Amna Sahar

amnasahar@gmail.com

1 Nofima, Norwegian Institute of Food, Fisheries, and Aquaculture Research, Muninbakken 9-13, 9291 Tromsø, Norway

2 Université Clermont Auvergne, INRAE, VetAgro Sup, UMRF, F-63370 Lempdes, France

3 Faculty of Food, Nutrition and Home Sciences, National Institute of Food Science and Technology, University of Agriculture Faisalabad, Faisalabad, Pakistan

4 Department of Food Engineering, Faculty of Agricultural Engineering \& Technology, University of Agriculture, Faisalabad, Pakistan

5 Centre for Nutrition and Food Sciences, Queensland Alliance for Agriculture and Food Innovation (QAAFI), The University of Queensland, Brisbane, Queensland 4072, Australia

\section{Introduction}

Meat and meat products play an important role in the human diet and health due to their content of high-quality protein, minerals, vitamins, and other nutrients (Kondjoyan et al. 2018; Xiong et al. 2014). However, the high perishability of such products requires the application of one or more conservation or processing methods. In this context, thermal processing methods have been most commonly used in order to accomplish two main objectives: (i) cooking food, i.e. make it flavourful and easier to chew and digest; (ii) ensuring food safety by inactivating pathogen microorganisms and enzymes. Thermal treatment concept refers to heating food at a certain temperature for a certain exposure time. Most meat and meat products are almost always subjected to some kind of heat treatment prior to consumption (Sun 2012; Taşkıran et al. 2020; Yu et al. 2017). Thermal treatments have even gained more attention in recent years due to the development of a wide variety of ready-to-eat products. These products are often consumed without further thermal treatments; thus, monitoring their core temperature is a critical control point with respect to 
quality and safety (O'Farrell et al. 2011; Wold et al. 2020). Traditional cooking methods, such as cooking in water and oven, have been widely used since ancient times. Due to the disadvantages of these methods, such as temperature gradient within the meat, reduced heating rate, long processing time, and negative changes on the quality of treated products, several new thermal technologies have emerged in recent years (Fig. 1).

Evaluation of heat-induced changes in meat has been traditionally performed by means of sensory and microbiological methods, as well as a wide range of physicochemical and biochemical techniques, such as protein oxidation and protein denaturation, lipid oxidation products, changes in cooking loss, and water holding capacity (WHC). As the application of most of these techniques is expensive and requires a long time and lots of consumables, to avoid the need for such measurements, thermally processed food is often overheated (Wold 2016; Wold et al. 2020; Hassoun et al. 2020). Although overheating ensures the safety of the treated products, the application of high temperature may affect the quality parameters, especially protein properties, such as protein denaturation, oxidation, and solubility, leading to reduced digestibility (Rakotondramavo et al. 2019; Hassoun et al. 2011). Therefore, efficient alternative screening methods are highly needed in order to avoid overheating or underheating and to monitor thermal processing in a continuous manner.

In recent years, there have been intense research efforts to develop non-destructive techniques based on spectroscopy to be applied in many fields; monitoring thermal treatments is one example of applications of these techniques. The application of spectroscopic techniques for monitoring thermal treatments relies on the basic assumption that optical properties, such as absorbance and scattering of treated food change upon heat treatments. Numerous spectroscopic techniques have been increasingly used in the last decade to evaluate changes in the quality of meat, resulting from the application of thermal treatments (Fig. 2). Figure 2 shows that from the year 2010, there has been a significant increase in the number of publications that report on the use of spectroscopic techniques for monitoring thermal treatments in foods of animal origin, especially meat and meat products. These include infrared-based spectroscopic techniques (González-Mohino et al. 2018; Ma et al. 2019; Perez-Palacios et al. 2019; Wold et al. 2020), nuclear magnetic resonance (NMR) (Han et al. 2019a; Sun et al. 2017), Raman spectroscopy (Berhe et al. 2015; Miyaoka et al. 2020), and fluorescence spectroscopy (Sahar et al. 2016; Mitra et al. 2018). However, to the best of our knowledge, there is still an obvious gap in the literature since no review has been published yet on this topic. Therefore, this review will span this gap by summarising the recent studies published during the last decade, investigating the potential of spectroscopic techniques for monitoring thermal treatments in meat.

\section{Heat Processing Methods}

\section{Traditional Thermal Processing Methods}

Meat and meat products are almost always subjected to some form of heat treatment prior to consumption (Deb-Choudhury
Fig. 1 Schematic illustration of thermal treatments applied to meat and meat products: processing methods and monitoring techniques. NMR nuclear magnetic resonance, SDS-PAGE sodium dodecyl sulfate-polyacrylamide gel electrophoresis, DSC differential scanning calorimetry

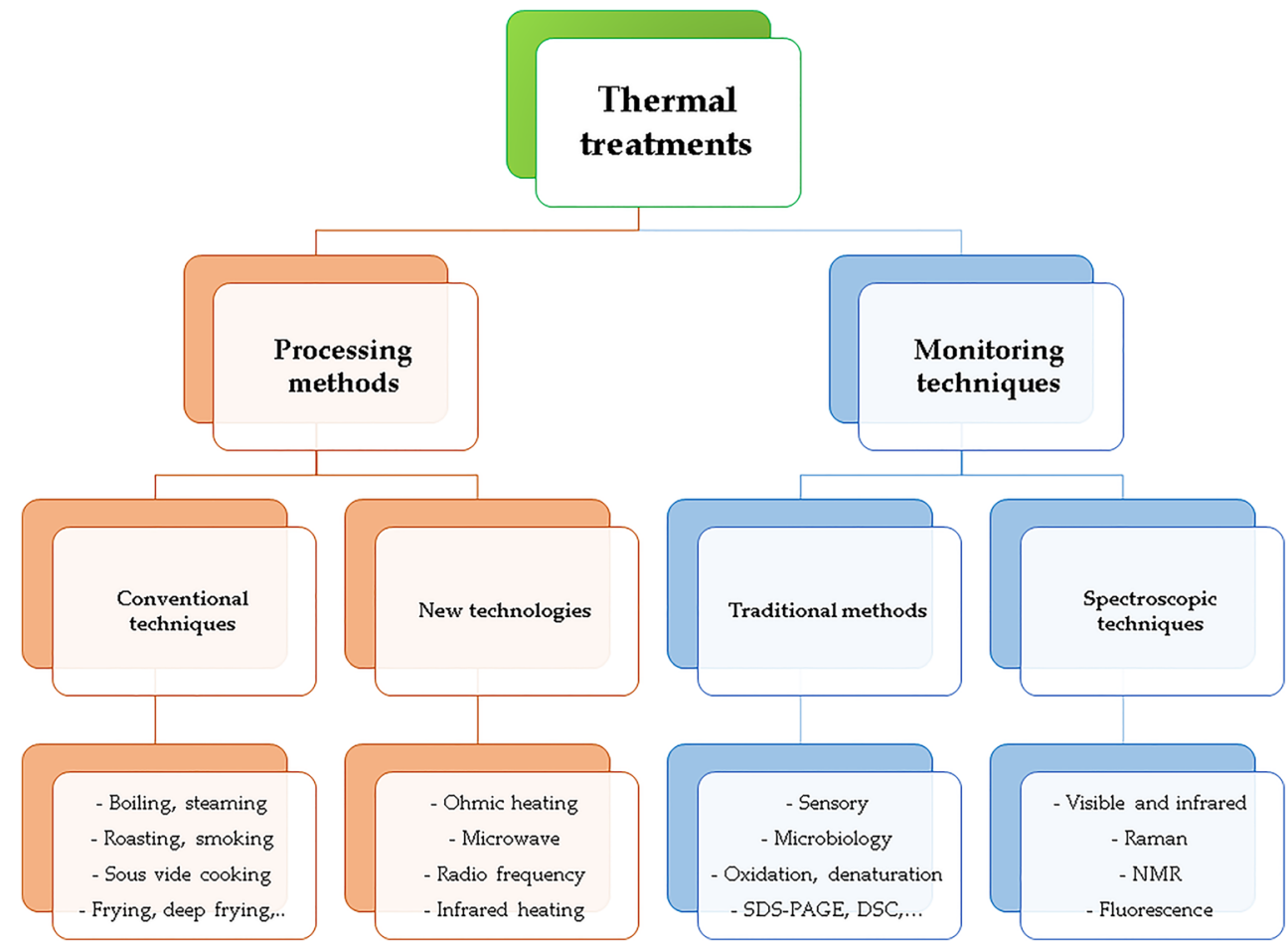




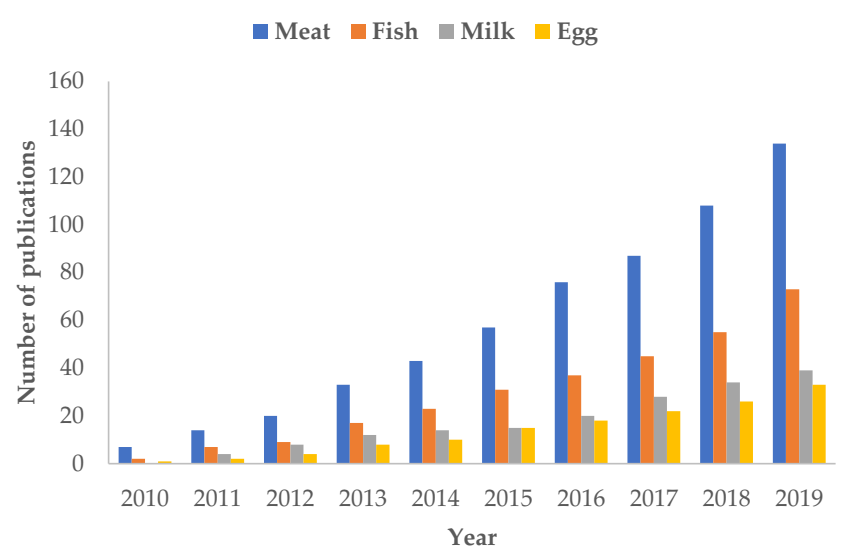

Fig. 2 Total number of publications of scientific articles reporting on application of spectroscopic techniques for monitoring thermal treatments in food of animal origin: Information obtained from the database Scopus the 26th April 2020 [Search criteria: Title-abstractkeywords (Thermal treatment) OR Article title-Abstract-Keywords (Cooking) AND Article title-Abstract-Keywords (Spectroscopy) AND Article title-Abstract-Keywords (Meat or fish or milk or egg)]

et al. 2014; Gatellier et al. 2009). Traditional cooking methods can be classified into two categories, namely moist-heat cooking, including water or steam as a cooking medium, such as boiling or poaching meat in water bath, sous-vide, and dryheat cooking, such as roasting, frying, and smoking. Each cooking method has its advantages and disadvantages. For example, boiling can be ideal for tough cuts of meat but it takes time and causes high loss of water-soluble vitamins and minerals that leach into the water, whereas smoking is used to enhance the flavour of chicken breasts, beef, pork, and other meats (McGee 2004; Sobral et al. 2018). Generally, the obtained results depend on cooking temperature, cooking time, heat transfer coefficient of the heating medium, form of heat transfer, nature of the cooked product, size, etc. The heterogeneous structure and differences in chemical composition (content of proteins, lipids, etc.) of meat make it difficult to achieve a uniform heat distribution as fat in meat, for example, does not generate and conduct the heat at the same rate as muscle does. More details about traditional cooking methods and their advantages and limitations can be found elsewhere (Pathare and Paul 2016; Sobral et al. 2018).

\section{Novel Technologies}

Conventional thermal processing of food could have several consequences on sensory quality (texture and colour), in addition to other challenges that include long cooking times, limited penetration, nonuniform heating, overheating, and underheating. In recent years, several promising thermal processing technologies, such as ohmic heating, microwave heating, radio frequency heating, and infrared heating, have emerged and some of them have been adopted by both consumers and the food industry. Numerous reports have been published in the literature describing the advantages that these emerging techniques have over traditional thermal processing (Chen et al. 2020; Chizoba Ekezie et al. 2017; Jaeger et al. 2016; Kubo et al. 2020). Modelling of heat transfer will not be discussed here as this topic is out of the scope of this review, and it was discussed in detail in other papers (Berk 2018; Erdogdu et al. 2018). However, it should be noted that conduction, convection, and radiation are the main forms of heat transfer in conventional thermal processing, whereas the product is heated internally and not through the meat surfaces in the case of new thermal technologies.

\section{Ohmic Heating}

In ohmic heat, a product is heated by passing an electrical current through it. The main features of this new thermal processing are short processing time, as the heat is generated internally, no need to heating medium, no hot or overheated surface, and no temperature gradient (Erdogdu et al. 2018; Jaeger et al. 2016). A wide number of studies have been focused on the advantages of ohmic heating over conventional thermal processing, such as water bath (Dai et al. 2014; Tian et al. 2016, 2020) and frying pan (Ángel-Rendón et al. 2019). Indeed, the previous studies reported that ohmic-treated pork batters and short shank samples presented several benefits, including (i) shorter cooking times, (ii) more uniform temperatures, and (iii) lower cooking loss compared to those treated with the other cooking methods.

\section{Microwave and Radio Frequency Heating}

Microwave and radio frequency heating are other interesting technologies that have gained widespread acceptance as effective thermal methods with the potential to replace conventional thermal processing. Ulrike ohmic heating, here the electrical energy is converted to electromagnetic radiation, which in turn interacts with the product and leads to heat generation (Chen et al. 2020; Chizoba Ekezie et al. 2017; Zhang et al. 2020a). These dielectric cooking methods enable short processing time, longer penetration depth, and ability to generate volumetric heat. Although microwave heating or reheating is widely used in households and food service, some challenges still need to be addressed in order to make microwave heating suitable for industrial use. The main obstacles include nonhomogeneous heating and high cost for the equipment, although various solutions have been proposed recently to overcome some of these limitations (Chizoba Ekezie et al. 2017). Numerous studies have reported the superiority of microwave heating compared to traditional water bath or oven (Calabrò and Magazù 2012; Han et al. 2019b; Li et al. 2019; Taşkıran et al. 2020). More details about these studies will be given in section 3. Less applications were found in the literature with 
respect to the use of radio frequency heating, and its application is still limited to thawing frozen foods.

\section{Infrared Heating}

Along with microwave and radio frequency, infrared radiation transfers thermal energy in the form of electromagnetic waves. Limited penetration depth due to slow heat transfer rate is the main challenge for this heating method, and thereby limited applications have been found in the literature reporting on the use of infrared heating in meat (Chen et al. 2020; Chizoba Ekezie et al. 2017; Erdogdu et al. 2018). Therefore, the infrared heating has been most commonly used as surface pasteurisation or to heat thin products. Another possible opportunity to improve the performance of this method includes its use as an auxiliary heating method or in combination with other heating treatments (Kendirci et al. 2014; Kor and Icier 2016; Yildiz Turp et al. 2016).

\section{Traditional Methods Used for Evaluating Changes in Meat During Cooking}

The application of thermal treatments leads to various changes in sensory and nutritional quality, microbiological load, as well as physicochemical and biochemical properties of the treated products. Several traditional methods have been widely used to evaluate these changes and to monitor thermal treatments. The changes in meat quality induced by the application of thermal treatments and the most used traditional assessment methods will be briefly discussed in the following section.

\section{Sensory and Microbiological Analysis}

It is well-known that thermal treatments induce changes in sensory properties, such as colour, tenderness, and flavour of meat and meat products. Sensory analysis can be performed by individuals (trained and consumer panels) who measure or estimate human responses to stimuli, but sensory evaluation can also be carried out through instrumental measurements. For example, meat colour is most commonly measured by colorimeters in CIE $L^{*}, a^{*}, b^{*}$ colour space, where $L^{*}$ refers to lightness (from 0 to 100 ), $a^{*}$ to redness (from -60 to 60 ), and $b *$ to yellowness (from -60 to 60 ). Mechanical properties of meat texture, such as tenderness and cohesiveness, have been widely measured instrumentally using Warner-Bratzler shear force and texture profile analysis (TPA). Apart from colour and texture, meat flavour (taste and odour) is also an important component of the sensory quality. Flavour compounds in meat are usually formed by thermal degradation of sugar, proteins, fat, and fatty acids (Chen et al. 2020; Li et al. 2019; Xiong et al. 2014). Food flavour and volatile compounds responsible for flavour are often determined by chromatographic techniques. Regarding microbiological examination, classical approaches based on culture media, such as total viable count, have been widely used as standard methods. However, in recent years, many promising alternative methods, especially molecular techniques, have been developed.

A large number of studies have been conducted in order to investigate the impact of various thermal treatments on the sensory properties and microbiological quality of meat by using traditional methods. For example, the impact of ohmic heating on colour and texture, among other quality attributes of pork meat, was investigated and compared to that of traditional water bath cooking (Dai et al. 2014). Although the ohmically cooked samples were processed several times more rapidly than the water bath-cooked samples, the authors observed better colour appearance in these samples compared to those which were cooked traditionally. However, a slightly harder texture was noticed for the pork meat samples cooked with ohmic heater, which was attributed to the formation of protein carbonyls and cross-links between proteins. Similar results were obtained on beef meat, with colour and tenderness properties of ohmically heated meat samples being better than those of water bath-cooked ones (Tian et al. 2016). Moreover, a recent study showed that ohmic heating results in more uniform temperature distribution and better microbiological inactivation compared to traditional water bath cooking (Tian et al. 2020).

Tenderness of meat is one of the most important eating quality parameters that determine the acceptance by consumers. The impact of three low-temperature cooking methods, i.e. water bath, microwave, and steam on meat tenderness as well as several other quality parameters of pork, was investigated at various times of heat treatment ( $\mathrm{Li}$ and Sun 2017). The best tenderness values were obtained when the pork samples were cooked with steam for $5 \mathrm{~min}$ or microwaved for $7 \mathrm{~min}$. In a recent study, the effect of microwave cooking on colour, texture, and volatile flavour compounds of yak meat was investigated and compared with traditional boiling cooking ( $\mathrm{Li}$ et al. 2019). Apart from the sample colour, the results showed an improved texture and better overall flavour of microwave-cooked samples compared to those of conventional boiling cooking. More recently, the microwave cooking was found to be more efficient for cooking thigh and breast chicken meat than a traditional oven (Taşkıran et al. 2020).

Little research was found in the literature, describing the impact of infrared cooking on quality changes of meat. One of these studies was conducted by Rahimi and co-authors, who investigated the impact of infrared cooking, as an alternative method to the traditional deep fat frying, on colour, texture, and other sensory properties of chicken nugget (Rahimi et al. 2018). The results showed that the infrared-cooked and control samples had a comparable acceptance, while a 
significantly lower fat content was observed for the samples cooked with infrared radiation, indicating a higher nutritional value compared to the deep fat fried samples.

\section{Changes in Nutritional Quality}

Nutritional quality of meat is often determined by its chemical composition, which includes the content of high-quality protein and essential amino acids, as well as the content of other nutrients (e.g. vitamins and minerals). However, underlying nutritional quality parameters such as protein digestibility and digestion rate, which are as important as the chemical composition, should be also taken into consideration when evaluating the nutritional quality of meat (Bax et al. 2012; DebChoudhury et al. 2014). These parameters are key factors that determine the release and bioavailability of proteins, peptides, and amino acids. Digestibility and digestion rate of meat proteins are often determined in vitro using pepsin and trypsin enzymes at $37{ }^{\circ} \mathrm{C}$ to mimic gastric and intestinal digestion, respectively. During thermal processing, biochemical and structural changes (denaturation, oxidation, and aggregation of proteins, the formation of intermolecular cross-links) can occur in meat protein, thus decreasing protein digestibility and digestion rate (Hassoun et al. 2011; Luo et al. 2018; Rakotondramavo et al. 2019). Numerous studies have reported that cooking temperature is the main factor that affects the protein digestion (Bax et al. 2012; Hassoun et al. 2011). Bax and co-workers (Bax et al. 2012) observed an increase in the digestion rate of ham protein when the meat was cooked at $70{ }^{\circ} \mathrm{C}$, while an inverse trend was observed when cooking the meat above $100{ }^{\circ} \mathrm{C}$, with a slight increase in the digestibility. The higher digestion speed at the low temperature was explained by protein denaturation and exposure of reactive protein sites, while protein oxidation and aggregation occurred at the high temperature, leading to a reduction in protein hydrolysis by the digestive proteases. In another study, in vitro gastrointestinal digestion of proteins from beef, chicken, pork, and kangaroo was studied after microwave and oven cooking (Luo et al. 2018). The impact of cooking on protein digestibility and digestion rate was found to be variable as it was influenced by cooking method, cooking condition, and cooked muscle foods. A more recent study reported a decrease in digestibility and an increase in digestion rate when ham meat was steam-cooked up to a core temperature of $65{ }^{\circ} \mathrm{C}$ (Rakotondramavo et al. 2019).

Cooking meat at high temperatures may cause the formation of heterocyclic aromatic amines (HAAs) and polycyclic aromatic hydrocarbon (PAHs) in addition to advanced glycation end products (AGEs), which are associated with various potential health hazards, such as the increased risk of chronic diseases and several types of cancer. These contaminant compounds are traditionally extracted, identified, and characterised using chromatographic methods and mass spectrometry (Dong et al. 2020; Sobral et al. 2018; Zhang et al. 2020b; Zhu et al. 2020). Numerous studies have indicated that HAA, PAH, and AGE contents vary according to, among others, the heating method used for cooking meat, and that higher temperatures result in higher amounts of these compounds. Roasting, grilling, frying, and smoking are generally known to generate higher amounts of these contaminants compared to milder cooking methods (Dong et al. 2020; Sobral et al. 2018; Zhang et al. 2020b).

\section{Evaluation of Biochemical Properties}

A number of heat-induced protein modifications in meat, i.e. protein denaturation and protein oxidation, changes in surface hydrophobicity and aggregation, have been reported in several studies as a result of the application of thermal treatments. These cooking-induced modifications are important to investigate and study due to their high impact on sensory and nutritional quality of treated products (Yu et al. 2016, 2017). Moreover, changes in cooking loss and WHC are also highly affected by protein denaturation and other modification in meat proteins.

Another traditional method that has been intensively applied to assess modifications in meat following heat treatment is oxidation and formation of Maillard reaction products. Conventional instrumental procedures such as sodium dodecyl sulfate polyacrylamide gel electrophoresis (SDS-PAGE) and differential scanning calorimetry (DSC) have been widely used as standard approaches in order to investigate thermal denaturation of protein and structural changes occurring during thermal treatments. SDS-PAGE allows the detection of changes in protein band intensity, while DSC exhibits multiple transition temperatures associated with protein denaturation. In addition to the electrophoresis techniques, more advanced proteomic methods, such as mass spectrometry and bioinformatics, have been also applied to investigate the impact of various thermal treatments (Deb-Choudhury et al. 2014; Miyaoka et al. 2020; Rakotondramavo et al. 2019).

Proteomic and several other approaches were used to monitor modifications in protein and amino acids resulting from boiling beef meat up to $4 \mathrm{~h}$ (Deb-Choudhury et al. 2014). The proteomic procedure showed that the heat exposure increased oxidative damage in protein of both the meat and the cooking water. In another study, similar approaches were used to reveal the impact of ohmic heating and traditional water bath on various quality parameters of beef meat (Tian et al. 2016). The results showed much less damages in the protein of ohmically cooked samples and less cooking loss compared with the samples cooked in the water bath, suggesting once again the benefit of ohmic heating as an emerging thermal processing technology. These results were confirmed recently by the same research group who noticed a better impact of ohmic heating on cooking loss, protein oxidation, and lipid oxidation of pork 
batter in comparison with water bath cooking (Tian et al. 2020).

Several studies have reported the impact of microwave heating on the structural changes of protein of meat in comparison with traditional water bath cooking ( $\mathrm{Li}$ et al. 2019; Han et al. 2019b). For example, a recent study showed that different microwave cooking conditions did not affect protein bands in SDS-PAGE electrophoresis of yak meat ( $\mathrm{Li}$ et al. 2019). Another study demonstrated an inhibitory effect of microwave cooking on surface hydrophobicity of beef proteins compared to water bath cooking (when heating at temperatures below $58^{\circ} \mathrm{C}$ ), while higher contents of total sulfhydryl groups were observed in the microwave-cooked samples (Han et al. 2019b).

The impact of boiling ( $\mathrm{Yu}$ et al. 2015) and roasting (Yu et al. 2016) on protein profile changes and modifications in amino acids in lamb meat was investigated using proteomic analysis. Roasted meat for a prolonged time showed a drastic reduction in band intensity of proteins on SDS-PAGE, plausibly caused by heat-induced cross-link formation, while actin and myoglobin bands remained visible even after $4 \mathrm{~h}$ of boiling. Oxidation of aromatic amino acids, the formation of Maillard reaction products, and protein fragmentation were among the heat-induced protein primary structural changes that were observed after roasting.

\section{Spectroscopic Monitoring Techniques}

Different spectroscopic methods have been developed in the last decades. These include mainly visible and vibrational spectroscopy, NMR, Raman, and fluorescence spectroscopy. The main features of these techniques are quantitative and qualitative analysis with high-speed measurements, nondestructive nature, no use of chemicals, and little or no preparation of samples. Most spectroscopic measurements can be performed using several modes depending on the position of the illumination source and detector. For example, when the illumination source and the detector are placed opposite to each, the light transmitted through the sample is captured and the mode is called transmittance (Fig. 3a), while the illumination source and the detector are placed parallel to each other in the interactance mode (Fig. 3b). These different measurement modes enable obtaining valuable insights into external and internal quality parameters of the examined sample.

The principle of monitoring thermal treatment by spectroscopic techniques is based on changes in optical properties, such as absorption and scattering, of muscle foods caused by protein denaturation and other structural and physical changes. Interaction of light with biological tissue is the result of a complex interplay between light scattering and absorption; scattering is associated with the structural and physical properties of the sample, while the absorption is mainly related to the chemical composition and concentration of the various chemical components that absorb light at different wavelengths in different manners. Several changes in the spectra occur as a result of the application of thermal treatments, which are mainly dominated by more scattering and less intense absorption, due to less absorbance from functional groups in water and proteins and other organic compounds (Elmasry and Nakauchi 2015; Hassoun et al. 2020; Wold et al. 2020; O'Farrell et al. 2011).

\section{Infrared Spectroscopic Techniques}

Infrared spectroscopy in the near (NIR) and mid (MIR) spectral ranges has been applied increasingly to food quality evaluation over the past decade due to its desirable features and more availability of instrumental methods in both research and industry. The NIR spectroscopy is based on molecular overtones and combination of fundamental vibrations, while the spectral signatures in the MIR region result from the fundamental vibrational modes (stretching, bending, and rotating) of the sample molecules (Cozzolino 2017).

The use of NIR spectroscopy has been proposed to predict a number of physicochemical and sensory characteristics of fresh or cooked products (e.g. pH, colour, fat content, drip loss, tenderness, juiciness, flavour, overall liking). However, little research is available on the prediction of various quality changes resulting from the application of different cooking methods or cooking conditions (Porep et al. 2015; Xiong et al. 2014). For example, González-Mohino et al. tried to evaluate the potential of NIR (850-1045 nm) spectroscopy to predict sensory attributes of pork meat (loins) subjected to different cooking conditions. Samples were oven-cooked at two temperatures $\left(150\right.$ and $\left.180{ }^{\circ} \mathrm{C}\right)$ for different times $(45$, 60 , and $75 \mathrm{~min}$ ) and confit-cooked for different times (120, 180, and $240 \mathrm{~min}$ ) (González-Mohino et al. 2018). Application of principal component analysis (PCA) showed a quite clear separation of the samples as a function of cooking temperature and cooking time. In addition, moderate to high correlations were observed between some sensory attributes of cooked samples, especially the confit-cooked ones (correlation coefficient $R$ was higher than 0.8 for most sensory parameters) and the NIR data. Using a similar approach, the same authors confirmed in a recent study the feasibility of using NIR for classifying pork samples as a function of cooking conditions. Again, $R$ values higher than 0.5 were observed between spectral data and some traditional quality parameters (e.g. texture parameters, cooking loss) (PerezPalacios et al. 2019).

It should be mentioned that the previous studies were conducted in controlled lab environments as fundamental research, which is far away from industrial applications in the real world. However, several reports have indicated the suitability of NIR for more successful inline applications in meat 
Fig. 3 Schematic representations of the two acquisition modes: transmittance (a) and interactance (b)

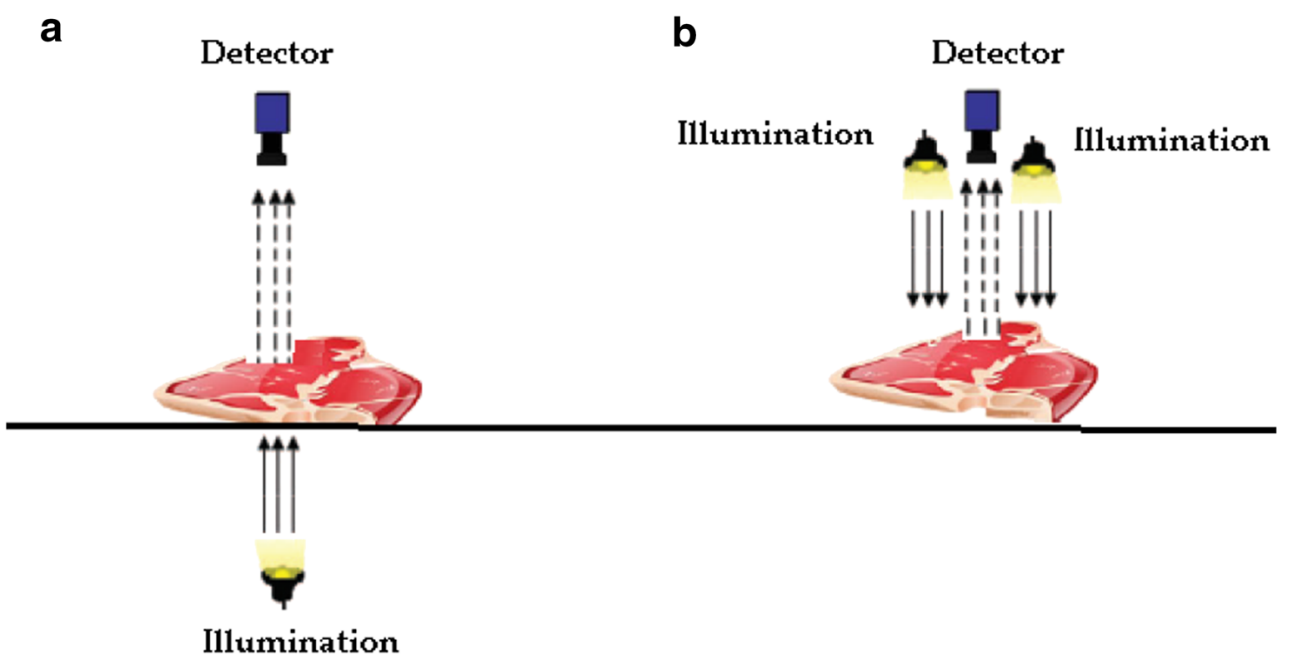

processing (Tschudi et al. 2018; Dixit et al. 2017). Thus, attempts have been made to apply NIR spectroscopy on conveyor belts in order to mimic the industrial processing of meat and meat products (O'Farrell et al. 2011; Wold et al. 2020). For instance, a study was conducted using NIR spectroscopy in interactance mode with the purpose of monitoring core temperature; a critical control parameter with respect to food quality, and in particular food safety, in baked liver pâté (O'Farrell et al. 2011). The results indicated that it was possible to estimate the core temperature with prediction errors in the range $1.5-4.3{ }^{\circ} \mathrm{C}$. These results were confirmed recently by Wold and others, who used a similar approach to monitor core temperature in sausages during industrial heat treatment in a steam oven (Wold et al. 2020). In this study, the best obtained accuracy for core temperature predicted by NIR spectroscopy was $\pm 1.0^{\circ} \mathrm{C}$. These two previous studies clearly demonstrated that NIR measurements, especially with interactance mode that allows light to travel further into the sample, are suitable for non-contact core temperature measurements in meat during heat treatment, thus paving the way for successful applications of NIR for inline analysis in real processes.

Recently, hyperspectral imaging (HSI) technique has been developed as a non-destructive and promising analytical tool that gathers valuable information about the spatial distribution of the materials within the sample along with spectral data (Xiong et al. 2014; Liu et al. 2018). One of the main features of HSI is the possibility of applying the optimised prediction model of measured quality attributes to each pixel of the image and to produce chemical images, thus visualising the amount and distribution of the measured parameters, such as moisture content and distribution (Kandpal et al. 2013) and colour parameters (Liu et al. 2018). The application of HSI on thermally processed meat has been highlighted in several recent studies (Liu et al. 2018; Ma et al. 2018, 2019; Kandpal et al. 2013).
An extensive number of studies can be found in the literature on the use of MIR spectroscopy in many applications. Especially Fourier transform mid-infrared (FTIR) spectroscopy has emerged as an effective and reliable analytical technique for identification and quantification of various quality attributes in muscle foods. The technique has gained increasing attention in recent years due to its versatility and costeffectiveness, allowing various applications in many fields. However, compared to NIR spectroscopy, less applications of MIR spectroscopy on monitoring thermal treatments have been reported in the literature (Table 1). This technique was used to highlight the effects of two microwave cooking settings (heating at $800 \mathrm{~W}$ for $95 \mathrm{~s}$ or at $650 \mathrm{~W}$ for $160 \mathrm{~s}$ ) and conventional convective heating (in an electric oven at the temperature of $165^{\circ} \mathrm{C}$ for $16 \mathrm{~min}$ ) on bovine meat (Calabrò and Magazù 2012). The FTIR results showed less alterations in the secondary structure of the protein and lower formation of Maillard reaction products in the microwave-cooked meat samples compared to those cooked in the conventional oven. Similarly, FTIR showed changes occurring in the secondary structure of the protein, especially transformation of $\alpha$-helix into $\beta$-sheets and increasing $\beta$-sheets, of meat batters cooked at a wide range of temperatures $\left(20-74^{\circ} \mathrm{C}\right)$ (Han et al. 2019a). Additionally, significant correlations were observed between the changes in protein structures and some traditional parameters, such as $L^{*}$ colour parameter $(R=-0.82), \mathrm{pH}(R=$ $-0.91)$, total sulfhydryl content $(R=0.92)$, and water loss.

\section{Raman Spectroscopy}

Raman spectroscopy has become one of the more promising and popular analytical tools in recent years. This technique has attractive characteristics, making it a versatile tool for food quality analysis. Raman spectroscopy is a scattering technique caused by a substance radiated with a monochromatic light, and the method is based on fundamental vibration modes that 
Table 1 Examples of most relevant studies that investigated the potential of spectroscopic techniques for monitoring thermal treatments in meat and meat products

\begin{tabular}{|c|c|c|c|c|}
\hline Product & Cooking method & $\begin{array}{l}\text { Spectroscopic } \\
\text { technique }\end{array}$ & Main results & Reference \\
\hline Pork & Oven and confit & NIR & $\begin{array}{l}\text { NIR was able to discriminate meat samples as a } \\
\text { function of cooking temperature and to some } \\
\text { extent cooking time }\end{array}$ & $\begin{array}{l}\text { González-Mohino } \\
\text { et al. (2018) }\end{array}$ \\
\hline Liver pâté & Oven & NIR & $\begin{array}{l}\text { Prediction core temperature with prediction errors } \\
\text { in the range of } 1.5-4.3{ }^{\circ} \mathrm{C}\end{array}$ & $\begin{array}{l}\text { O'Farrell et al. } \\
\text { (2011) }\end{array}$ \\
\hline Pork & Water bath & NIR & $\begin{array}{l}\text { NIR was able to classify meat samples cooked for } \\
\text { different times }\end{array}$ & $\begin{array}{l}\text { Perez-Palacios } \\
\quad \text { et al. (2019) }\end{array}$ \\
\hline Sausages & Steam oven & NIR & $\begin{array}{l}\text { Prediction core temperature of sausage with a quite } \\
\text { high accuracy }\end{array}$ & Wold et al. (2020) \\
\hline $\begin{array}{r}\text { Chicken } \\
\text { breast }\end{array}$ & Oven & $\begin{array}{l}\text { VIS/NIR HSI } \\
\qquad(400-1000 \mathrm{~nm})\end{array}$ & $\begin{array}{l}\text { Visualisation of moisture content of meat samples } \\
\text { cooked at three different temperatures, using } \\
\text { chemical images (distribution maps) generated } \\
\text { from HSI data }\end{array}$ & $\begin{array}{l}\text { Kandpal et al. } \\
\text { (2013) }\end{array}$ \\
\hline Beef & Microwave & $\begin{array}{l}\text { VIS/NIR HSI } \\
\quad(400-1000 \mathrm{~nm})\end{array}$ & $\begin{array}{l}\text { Visualisation distribution maps of colour parameters } \\
\text { of meat samples exposed to different microwave } \\
\text { heating times }\end{array}$ & Liu et al. (2018) \\
\hline $\begin{array}{c}\text { Bovine } \\
\text { breast } \\
\text { meat }\end{array}$ & $\begin{array}{l}\text { Microwave and } \\
\text { conventional oven }\end{array}$ & FTIR & $\begin{array}{l}\text { Increased contents of carbonyl and methylene in } \\
\text { conventionally cooked samples, indicating more } \\
\text { Maillard reaction products }\end{array}$ & $\begin{array}{l}\text { Calabrò and } \\
\text { Magazù (2012) }\end{array}$ \\
\hline Meat batters & Water bath & FTIR and NMR & $\begin{array}{l}\text { Spectroscopic techniques provided valuable information } \\
\text { about water distribution, protein conformation, and } \\
\text { structural changes in proteins occurring at phase } \\
\text { transition temperatures }\end{array}$ & Han et al. (2019a) \\
\hline $\begin{array}{r}\text { Chicken } \\
\text { meat }\end{array}$ & $\begin{array}{l}\text { Isothermal heat } \\
\text { treatment }\end{array}$ & Raman & $\begin{array}{l}\text { Amide I Raman band was sufficient to be used as a } \\
\text { marker for prediction of heat treatment conditions }\end{array}$ & $\begin{array}{l}\text { Miyaoka et al. } \\
\quad(2020)\end{array}$ \\
\hline Pork & Water bath & Raman & $\begin{array}{l}\text { High correlations were found between Raman spectra } \\
\text { and cooking loss, cooking temperature, and cooking time }\end{array}$ & Berhe et al. (2014) \\
\hline Pork & Water bath & $\begin{array}{l}\text { Raman and } \\
\text { fluorescence }\end{array}$ & $\begin{array}{l}\text { High accuracy of prediction of core temperature even } \\
\text { after several days of storage }\end{array}$ & Berhe et al. (2015) \\
\hline Pork & - & NMR & $\begin{array}{l}\text { Significant correlations were obtained between NMR } \\
\text { data and other traditional measurements }\end{array}$ & Han et al. (2014) \\
\hline Sausage & Water bath & NMR, Raman & $\begin{array}{l}\text { NMR distinguished fat and water proton mobility and } \\
\text { Raman spectroscopy quantified changes in secondary } \\
\text { protein structures in samples heated for different times }\end{array}$ & Yang et al. (2016) \\
\hline Beef & Water bath & NMR, MRI & $\begin{array}{l}\text { Demonstrating the impact of cooking temperature on } \\
\text { protein denaturation and water distribution, as well as } \\
\text { visualisation different levels of water contents in samples } \\
\text { heated at different temperature-time combinations }\end{array}$ & Sun et al. (2017) \\
\hline $\begin{array}{r}\text { Bovine } \\
\text { meat }\end{array}$ & Steam & Fluorescence & $\begin{array}{l}\text { Fluorescence spectroscopy in EEM mode coupled with } \\
\text { PARAFAC analysis enabled discrimination of meat } \\
\text { samples cooked at high temperature for different times }\end{array}$ & Sahar et al. (2009) \\
\hline $\begin{array}{r}\text { Bovine } \\
\text { meat }\end{array}$ & Steam & Fluorescence & $\begin{array}{l}\text { Fluorescence intensity after excitation at } 360 \mathrm{~nm} \text { increased } \\
\text { with increasing cooking temperature in agreement with } \\
\text { increases in protein and lipid oxidation products }\end{array}$ & $\begin{array}{l}\text { Gatellier et al. } \\
\text { (2009) }\end{array}$ \\
\hline $\begin{array}{r}\text { Bovine } \\
\text { meat }\end{array}$ & Steam & Fluorescence & $\begin{array}{l}\text { Fluorescence spectroscopy in EEM enabled good prediction } \\
\text { of heterocyclic aromatic amines in meat cooked at high } \\
\text { temperature for different cooking times }\end{array}$ & Sahar et al. (2010) \\
\hline $\begin{array}{r}\text { Bovine } \\
\text { meat }\end{array}$ & Boiling & Fluorescence & $\begin{array}{l}\text { A significant increase in fluorescence was observed in both } \\
\text { cooked meat and cooking water at the beginning of boiling, } \\
\text { followed by smaller changes at later times }\end{array}$ & $\begin{array}{l}\text { Deb-Choudhury } \\
\text { et al. (2014) }\end{array}$ \\
\hline $\begin{array}{r}\text { Bovine } \\
\text { meat }\end{array}$ & Water bath and steam & Fluorescence & $\begin{array}{l}\text { EEM fluorescence spectroscopy in combination with } \\
\text { PARAFAC was able to discriminate meat samples as a } \\
\text { function of both cooking temperature and time }\end{array}$ & Sahar et al. (2016) \\
\hline Pork & Autoclave and oven & Fluorescence & $\begin{array}{l}\text { Fluorescence of tryptophan and Schiff's bases were } \\
\text { successfully } \\
\text { used as markers for oxidation in protein, occurring during cooking treatments } \\
\text { with various time-temperature combinations }\end{array}$ & Mitra et al. (2018) \\
\hline
\end{tabular}

PARAFAC parallel factor analysis, EEM excitation-emission matrix, VIS/NIR visible near-infrared spectroscopy, NMR nuclear magnetic resonance, $M R I$ magnetic resonance imaging, FTIR Fourier-transform infrared spectroscopy, HSI hyperspectral imaging 
take place in the ground electronic state of molecules (Damez and Clerjon 2013; Yang et al. 2019).

Numerous studies have been carried to investigate the potential of Raman spectroscopy for monitoring thermal treatments in meat (Table 1). One example is a study conducted by $\mathrm{Xu}$ and others, who used Raman spectroscopy to study the evolution of structural changes occurring in pork myofibrillar proteins and relationships with the TPA textural parameters during heat-induced gelation (Xu et al. 2011). The results pointed out a decrease in $\alpha$-helix content with an increase in $\beta$-sheets, $\beta$-turns, and random coil contents with increasing cooking temperature. In addition, PCA applied to Raman and texture data showed significant correlations between these structural changes and the hardness of heat-induced gels. In another study, prediction of cooking temperature and cooking time of pork meat heat-treated in a water bath at 50 to $70{ }^{\circ} \mathrm{C}$ for 2-10 h was investigated using Raman spectroscopy (Berhe et al. 2014). PCA showed good discrimination between samples cooked at low temperatures (below $60^{\circ} \mathrm{C}$ ) and high temperatures (above $60^{\circ} \mathrm{C}$ ) with the bands at amide I, amide III, and disulfide bond regions being the most important spectral regions for this discrimination. Predictions of cooking temperature $\left(R^{2}=0.96\right)$, cooking time $\left(R^{2}=0.78\right)$, and cooking loss $\left(R^{2}=0.82\right)$ were successfully carried out using the Raman spectra. The same research group successfully used Raman spectroscopy to predict the endpoint temperature in pork meat cooked at temperatures ranging from 50 to $80{ }^{\circ} \mathrm{C}$ for $2 \mathrm{~h}$ (Berhe et al. 2015). A squared correlation coefficient of $R^{2}=0.98$ and a prediction error of less than $1.7^{\circ} \mathrm{C}$ were obtained. Moreover, the results showed that Raman was able to classify cooked meat with endpoint temperature of below and above $65{ }^{\circ} \mathrm{C}$ with a correct classification rate of more than $97 \%$. As a result of such promising findings, the authors concluded that Raman spectroscopy has great potential for the meat industry. These results were confirmed by a recent study (Miyaoka et al. 2020), in which Raman spectroscopy was used to estimate heat treatment conditions of chicken meat based on the amide I peak position. SDS-PAGE analysis exhibited denaturation of myosin and actin in the temperature range of $60-80{ }^{\circ} \mathrm{C}$, which was consistent with the Raman spectral results.

\section{Nuclear Magnetic Resonance}

Nuclear magnetic resonance (NMR) spectroscopy is a rapid and non-destructive technique that is used for providing structural information about organic compounds in biological samples. In this method, the magnetic properties of specific atomic nuclei are used to explore the information present in organic compounds. The sample is placed in the magnetic field and radio frequency pulse is used to excite the atomic nuclei. The amount of energy absorbed by atomic nuclei is directly related to the number of specific nucleus present in the studied sample. The principal NMR methods include high-resolution NMR (HR-NMR), low field NMR (LF-NMR), and magnetic resonance imaging (MRI). NMR has been used for a wide range of analyses in food systems including quality evaluation of meat. The most relevant applications of NMR are water mobility and distribution, water content, and WHC (Damez and Clerjon 2013).

Numerous studies have demonstrated that NMR and MRI can be used to monitor changes in meat during cooking through identifying important temperatures at which major changes in meat structure occur (Table 1). For example, LFNMR with transverse relaxation time $T_{2}$ and MRI were investigated in order to optimise heating temperature and time of Chinese braised beef and provide insights into changes in protein-water interactions during heating treatment (Sun et al. 2017). The results showed a significant impact of heating temperature on both water distribution and protein denaturation, while the effect of cooking time was less pronounced. In another study, LF-NMR $T_{2}$ relaxation times were used to study changes in gelling of pork myofibrillar proteins and modifications of WHC, occurring in the course of heating (Han et al. 2014). A significant change of $T_{2}$ occurred when increasing heating temperatures. Moreover, significant correlations were obtained between relaxometry data and the gel network microstructural data. Recently, the relationships between protein conformation, free water, and hydration water were studied in meat batters at different phase transition temperatures using LF-NMR (Han et al. 2019a). A decrease in WHC significantly was observed at $50{ }^{\circ} \mathrm{C}$, and immobilised water was gradually exchanged into free water. An MRI method was developed in situ to provide simultaneous information about changes in muscle structure and internal water transfer during beef heating from 20 to 75 (Bouhrara et al. 2012). This technique considers spatial variations of temperature in the sample and maps deformation and water content. By using this technique, the authors successfully modelled water transfer, evolution of water mobility as a function of protein denaturation, and deformation during cooking.

\section{Fluorescence Spectroscopy}

Fluorescence spectroscopy is based on the principle that any molecule of biological samples could absorb energy in the form of light (ultraviolet or visible). This energy leads the electron of that molecule to a higher energy level, and when the electron returns to its initial ground state, the energy is lost in the form of light/fluorescence. An emission spectrum can be obtained by fixing the excitation wavelength and vice versa. This type of measurement is the most commonly used mode of fluorescence spectroscopy and allows one to obtain two-dimensional spectra (either excitation spectra or emission spectra). Recent advances in spectroscopic techniques lead to fluorescence landscape, commonly known as excitation- 
emission matrix (EEM). In this case, multiple emission spectra (or excitation spectra) at different excitation wavelengths (or emission wavelengths) can be recorded simultaneously. There is another form of fluorescence spectroscopy known as synchronous fluorescence spectroscopy (SFS), in which spectra are collected by moving both excitation and emission wavelengths and keeping a constant distance $(\Delta \lambda)$ between them (Hassoun et al. 2019).

Fluorescence spectroscopy is a non-invasive, non-destructive, rapid, and sensitive technique that provides useful information about fluorescent molecules present in the investigated sample and their environment. It has been widely used to investigate the changes occurring during the application of thermal treatment in meat (Table 1). Gatellier and coworkers fixed the excitation at $360 \mathrm{~nm}$ to collect fluorescence emission spectra between 390 and $600 \mathrm{~nm}$ and related this spectral region to the meat oxidation caused by cooking (Gatellier et al. 2009). A significant increase in fluorescence was observed after raising the temperature of meat surface above $141{ }^{\circ} \mathrm{C}$. The authors attributed the increase in fluorescence to the interaction between proteins and aldehyde products of lipid peroxidation. The correlation results showed that approximately $80 \%$ of this fluorescence can be explained by protein carbonyl group formation. These findings are consistent with those of a recently published study (Mitra et al. 2018), reporting changes in both fluorescence intensity and peak maximum emission of tryptophan and Schiff's bases in pork meat subjected to different cooking treatments.

Sahar and co-authors (Sahar et al. 2009) investigated the possibility of using SFS combined with chemometrics to determine the effect of different thermal treatments on cooked meat quality. Bovine samples cooked at different temperatures for various cooking times were examined and fluorescence landscape spectra (EEM) were collected in the 250- to 550$\mathrm{nm}$ wavelength range. The data from SFS landscape (1080 spectra) were studied using Parallel Factors (PARAFAC) model. The obtained results exhibited changes in meat fluorescent compounds during cooking as a function of both cooking temperature and cooking time. Figure 4 a represents the three-dimensional fluorescence plot obtained from the sample of raw meat. A very intense peak at about $295 \mathrm{~nm}$ can be observed, originating from the fluorescence of tryptophan residues in the protein. However, a different peak can be seen in three-dimensional landscape of meat samples that were cooked at $237^{\circ} \mathrm{C}$ for $10 \mathrm{~min}$ (Fig. 4b). It can be observed that the peak that was present at about $290 \mathrm{~nm}$ in the raw meat sample became less intense in cooked meat samples, whereas a new spectral peak emerged gradually at $470 \mathrm{~nm}$ for the heattreated meat samples (Sahar et al. 2009). In Fig. 5, the synchronous fluorescence spectra of meat samples were presented. These meat samples were cooked for $0,2,5$, and $7 \mathrm{~min}$ at $237^{\circ} \mathrm{C}$. Intense peak at about $295 \mathrm{~nm}$ (assigned to tryptophan residues) was observed in raw meat samples whereas the
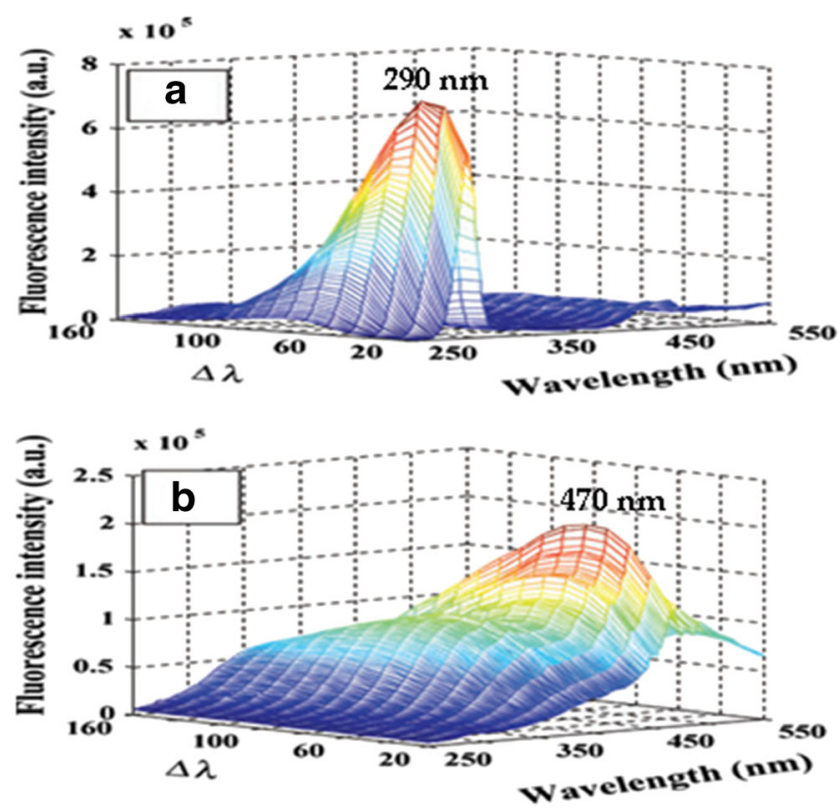

Fig. 4 Synchronous fluorescent landscape (excitation-emission matrix, EEM) of meat: a EEM for uncooked meat samples, b EEM for meat samples cooked for $10 \mathrm{~min}$ at $237^{\circ} \mathrm{C}$

samples cooked for 2 min showed a prominent peak at $355 \mathrm{~nm}$ and another peak at $468 \mathrm{~nm}$. However, meat samples cooked for more than 5 min showed maximum excitation at $468 \mathrm{~nm}$, and less intense peak in the range of 350 to $450 \mathrm{~nm}$. The results demonstrated in Fig. 5 showed that the peak representing tryptophan residues disappeared in cooked meat samples that can be related to the degradation or modification of protein during cooking. In addition, the peak at $294 \mathrm{~nm}$ displaced to $355 \mathrm{~nm}$ after 2 min of cooking and shifted to $468 \mathrm{~nm}$ for the samples cooked for more than $5 \mathrm{~min}$. This new peak at $468 \mathrm{~nm}$ along with the spectral band at 350 $550 \mathrm{~nm}$ corresponds to the Maillard compounds formed during the cooking of meat (Sahar et al. 2016). In another study, fluorescence spectroscopy in EEM mode was used to investigate changes in the environment of the aromatic amino acids of pork samples heated in water bath for $2 \mathrm{~h}$ at different temperatures from 50 to $80{ }^{\circ} \mathrm{C}$ with an interval of $2{ }^{\circ} \mathrm{C}$ (Berhe et al. 2015). Generally, the results showed a decrease in fluorescence emission intensity (measured at wavelengths from 280 to $430 \mathrm{~nm}$ with excitation wavelength from 240 to $320 \mathrm{~nm}$ ) as the temperature increased from 50 to $80^{\circ} \mathrm{C}$.

As reported previously, during cooking, especially at hightemperature cooking, HAA can be formed. The potential of SFS was investigated to detect and identify the production of HAA in bovine meat during cooking at high temperatures (grilling) for several cooking times (Sahar et al. 2010). Four HAA and their concentrations were successfully predicted from SFS data using two components of PARAFAC. In another study, fluorescence spectroscopy and microscopy approaches were used to illustrate heat-induced modifications 
Fig. 5 Synchronous fluorescence spectra recorded at $\Delta \lambda=80 \mathrm{~nm}$ for the meat samples cooked for 0 , 2,5 , and $7 \mathrm{~min}$ at 237

${ }^{\circ} \mathrm{C}$.

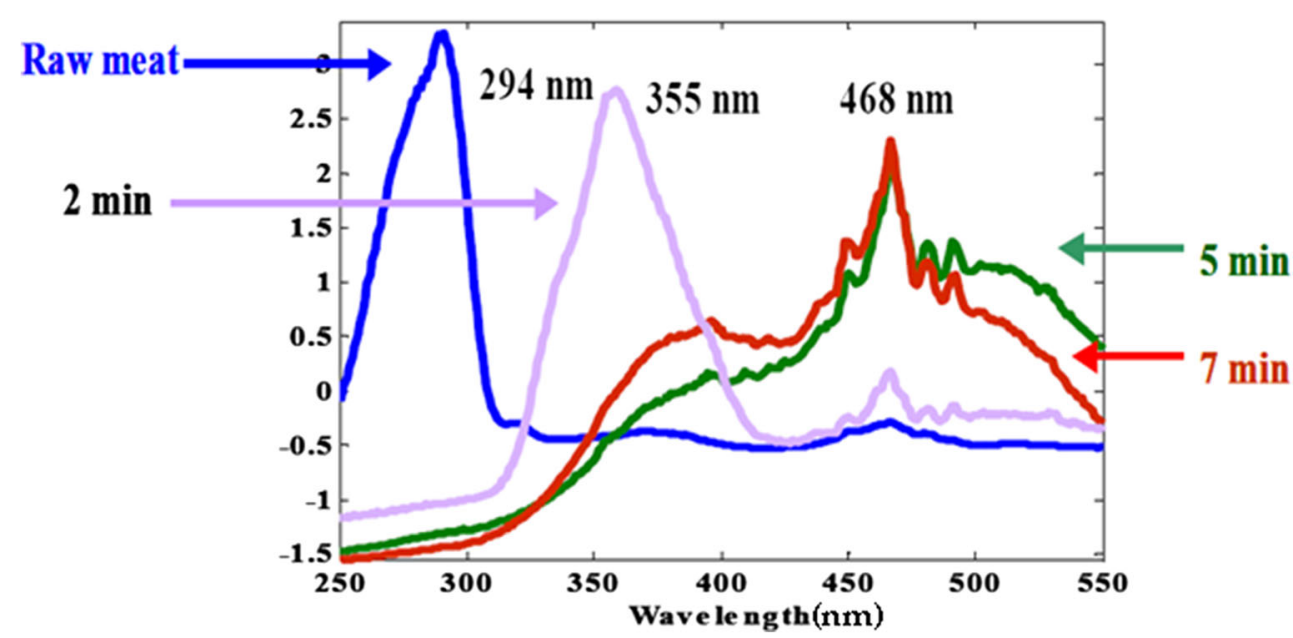

at macroscopic and microscopic levels of minced beef samples boiled under reflux for $0,15,30,60$, or $240 \mathrm{~min}$ (DebChoudhury et al. 2014). The results indicated a rapid increase in fluorescence as cooking progressed during the first $30 \mathrm{~min}$, which was attributed to the formation of AGEs, followed by a smaller change during the last $180 \mathrm{~min}$ of cooking time.

\section{Conclusions and Future Trends}

This review has summarised some of the most relevant and recent studies reporting on the application of spectroscopic techniques for monitoring thermal treatments in meat. In light of the reviewed literature, it is clear that a significant potential exists for the application of several spectroscopic techniques (e.g. infrared spectroscopy, Raman, NMR, and fluorescence spectroscopy) to assess changes in meat quality as induced by thermal treatments in a rapid and non-destructive way. However, these techniques are still not widely adopting in practice in the meat industry, and process and production lines continue to employ traditional approaches to perform the control task. Indeed, except for some recent attempts, based on inline applications on conveyor belts to mimic the industrial environment, our literature research revealed that most studies have been conducted at a laboratory scale. This is because some challenges are still to be addressed before moving from controlled lab measurements to realistic applications in the meat processing industry.

On the one hand, some challenges are related to the meat matrix itself, while others are associated with thermal treatment methods (e.g. traditional thermal processing). In more detail, heterogeneity and variation in meat and meat products in terms of both chemical composition and physical characteristics, such as size and shape, are important challenges that need to be addressed in order to make an accurate quality assessment of these products. The temperature gradient from the surface and down toward the core of the treated samples, the time required for the heating, and the alteration in sensory properties of heat-treated samples are some of the main challenges related to thermal treatment methods. Recent studies have shown that some of these limitations can be addressed by applying new thermal processing techniques. Although the use of some of these new technologies, such as microwave and ohmic heating, has been well documented, other thermal processing methods, such as infrared heating and radio frequency, are yet to be investigated more in future studies.

On the other hand, difficulties remain with regard to the implementation of novel assessment and analytical techniques (e.g. spectroscopic techniques) in the food industry. Many of these obstacles are cost-related while other barriers are more broadly community-based due to reluctance of industry and research organisations to adopt new technologies. Nevertheless, recent advances in spectroscopy and imaging (such as HSI, which is more suitable for inline monitoring) make them more likely to become a technology of choice not only in industry but also in everyday life applications. HSI has been widely coupled with visible and near-infrared spectroscopy, whereas its combination with other spectroscopic modes such as fluorescence should be investigated more in future research. The design and implementation of optical instrumentations in a way that permits light to travel deeper in meat samples may help to obtain a more representative spectroscopic signal from the inner parts of the sample. This is for example possible by designing a spectroscopic system based on the interactance mode, thus collecting signals that have interacted inside the sample.

In summary, the main goal of the present review was to highlight the potentiality of spectroscopic techniques to detect changes in the quality of meat following the application of thermal treatments. Further research should be carried out focusing on both more inline spectroscopic applications and more investigations of emerging thermal processing technologies. Several challenges still to be addressed before converting research into applied spectroscopic opportunities 
through commercially successful applications. It is our opinion that once perfected, several spectroscopic techniques will be used as effective tools for real-time quality control in the meat processing and other food industries.

Acknowledgements Open Access funding provided by Nofima the food research institute.

Open Access This article is licensed under a Creative Commons Attribution 4.0 International License, which permits use, sharing, adaptation, distribution and reproduction in any medium or format, as long as you give appropriate credit to the original author(s) and the source, provide a link to the Creative Commons licence, and indicate if changes were made. The images or other third party material in this article are included in the article's Creative Commons licence, unless indicated otherwise in a credit line to the material. If material is not included in the article's Creative Commons licence and your intended use is not permitted by statutory regulation or exceeds the permitted use, you will need to obtain permission directly from the copyright holder. To view a copy of this licence, visit http://creativecommons.org/licenses/by/4.0/.

\section{References}

Ángel-Rendón, S. V., Filomena-Ambrosio, A., Cordon-Díaz, S., BenítezSastoque, E. R., \& Sotelo-Díaz, L. I. (2019). Ohmic cooking: application of a novel technology in pork and influences on water holding capacity, cooking loss and colour. International Journal of Gastronomy and Food Science, 17(April), 100164. https://doi.org/ 10.1016/j.ijgfs.2019.100164.

Bax, M. L., Aubry, L., Ferreira, C., Daudin, J. D., Gatellier, P., Rémond, D., \& Santé-Lhoutellier, V. (2012). Cooking temperature is a key determinant of in vitro meat protein digestion rate: investigation of underlying mechanisms. Journal of Agricultural and Food Chemistry, 60(10), 2569-2576. https://doi.org/10.1021/jf205280y.

Berhe, D. T., Engelsen, S. B., Hviid, M. S., \& Lametsch, R. (2014). Raman spectroscopic study of effect of the cooking temperature and time on meat proteins. Food Research International, 66, 123131. https://doi.org/10.1016/J.FOODRES.2014.09.010.

Berhe, D. T., Lawaetz, A. J., Engelsen, S. B., Hviid, M. S., \& Lametsch, R. (2015). Accurate determination of endpoint temperature of cooked meat after storage by Raman spectroscopy and chemometrics. Food Control, 52, 119-125. https://doi.org/10. 1016/J.FOODCONT.2014.12.011.

Berk, Z. (2018). Food process engineering and technology (third edition). Cambridge, MA, USA: Academic Press.

Bouhrara, M., Clerjon, S., Damez, J. L., Kondjoyan, A., \& Bonny, J. M. (2012). In situ imaging highlights local structural changes during heating: the case of meat. Journal of Agricultural and Food Chemistry, 60(18), 4678-4687. https://doi.org/10.1021/jf2046569.

Calabrò, E., \& Magazù, S. (2012). Comparison between conventional convective heating and microwave heating: an FTIR spectroscopy study of the effects of microwave oven cooking of bovine breast meat. Journal of Electromagnetic Analysis and Applications, 04(11), 433-439. https://doi.org/10.4236/jemaa.2012.411060.

Chen, F., Zhang, M., Fan, K., \& Mujumdar, A. S. (2020). Non-thermal technology and heating technology for fresh food cooking in the central kitchen processing: a review. Food Reviews International, 9129. https://doi.org/10.1080/87559129.2020.1740246.

Chizoba Ekezie, F.-G., Sun, D.-W., Han, Z., \& Cheng, J.-H. (2017). Microwave-assisted food processing technologies for enhancing product quality and process efficiency: a review of recent developments. Trends in Food Science \& Technology, 67, 58-69. https://doi.org/10.1016/J.TIFS.2017.05.014.

Cozzolino, D. (2017). Vibrational spectroscopy. In A. Georgiou \& G. P. Danezis (Eds.), Food authentication: Management, analysis and regulation. John Wiley \& Sons Ltd.

Dai, Y., Lu, Y., Wu, W., Lu, X., Han, Z., Liu, Y., Li X.M., Dai R.T. (2014). Changes in oxidation, color and texture deteriorations during refrigerated storage of ohmically and water bath-cooked pork meat. Innovative Food Science and Emerging Technologies, 26, 341-346. https://doi.org/10.1016/j.ifset.2014.06.009.

Damez, J.-L., \& Clerjon, S. (2013). Quantifying and predicting meat and meat products quality attributes using electromagnetic waves: an overview. Meat Science, 95(4), 879-896. https://doi.org/10.1016/J. MEATSCI.2013.04.037.

Deb-Choudhury, S., Haines, S., Harland, D., Clerens, S., Van Koten, C., \& Dyer, J. (2014). Effect of cooking on meat proteins: mapping hydrothermal protein modification as a potential indicator of bioavailability. Journal of Agricultural and Food Chemistry, 62(32), 8187-8196. https://doi.org/10.1021/jf502668w.

Dixit, Y., Casado-Gavalda, M. P., Cama-Moncunill, R., CamaMoncunill, X., Markiewicz-Keszycka, M., Cullen, P. J., \& Sullivan, C. (2017). Developments and challenges in online NIR spectroscopy for meat processing. Comprehensive Reviews in Food Science and Food Safety, 16(6), 1172-1187. https://doi.org/ 10.1111/1541-4337.12295.

Dong, H., Xian, Y., Li, H., Bai, W., \& Zeng, X. (2020). Potential carcinogenic heterocyclic aromatic amines (HAAs) in foodstuffs: formation, extraction, analytical methods, and mitigation strategies. Comprehensive Reviews in Food Science and Food Safety, 19(2), 365-404. https://doi.org/10.1111/1541-4337.12527.

Elmasry, G., \& Nakauchi, S. (2015). Noninvasive sensing of thermal treatments of Japanese seafood products using imaging spectroscopy. International Journal of Food Science and Technology, 50(9), 1960-1971. https://doi.org/10.1111/ijfs. 12863.

Erdogdu, F., Karatas, O., \& Sarghini, F. (2018). A short update on heat transfer modelling for computational food processing in conventional and innovative processing. Current Opinion in Food Science, 23, 113-119. https://doi.org/10.1016/J.COFS.2018.10.003.

Gatellier, P., Santé-Lhoutellier, V., Portanguen, S., \& Kondjoyan, A. (2009). Use of meat fluorescence emission as a marker of oxidation promoted by cooking. Meat Science, 83(4), 651-656. https://doi. org/10.1016/J.MEATSCI.2009.07.015.

González-Mohino, A., Antequera, T., Ventanas, S., Caballero, D., MirBel, J., \& Pérez-Palacios, T. (2018). Near-infrared spectroscopybased analysis to study sensory parameters on pork loins as affected by cooking methods and conditions. Journal of the Science of Food and Agriculture, (August 2017). https://doi.org/10.1002/jsfa.8944.

Han, M., Wang, P., Xu, X., \& Zhou, G. (2014). Low-field NMR study of heat-induced gelation of pork myofibrillar proteins and its relationship with microstructural characteristics. Food Research International, 62, 1175-1182. https://doi.org/10.1016/j.foodres. 2014.05.062.

Han, Z., Zhang, J., Zheng, J., Li, X., \& Shao, J. H. (2019a). The study of protein conformation and hydration characteristics of meat batters at various phase transition temperatures combined with low-field nuclear magnetic resonance and Fourier transform infrared spectroscopy. Food Chemistry, 280(August 2018), 263-269. https://doi.org/ 10.1016/j.foodchem.2018.12.071.

Han, Z., Cai, M., Cheng, J.-H., \& Sun, D.-W. (2019b). Effects of microwave and water bath heating on the interactions between myofibrillar protein from beef and ketone flavour compounds. International Journal of Food Science \& Technology, 1-7. https://doi.org/10. 1111/ijfs. 14079.

Hassoun, A., Santé-Lhoutellier, V., Lebert, A., Kondjoyan, A., \& J.D., D (2011). Incidence of various process parameters on in vitro protein 
digestion of beef meat. 57th International Congress of Meat Science and Technology, (August), 1-4.

Hassoun, A., Sahar, A., Lakhal, L., \& Aït-Kaddour, A. (2019). Fluorescence spectroscopy as a rapid and non-destructive method for monitoring quality and authenticity of fish and meat products: impact of different preservation conditions. LWT, 103, 279-292. https://doi.org/10.1016/j.lwt.2019.01.021.

Hassoun, A., Cropotova, J., Rustad, T., Heia, K., Lindberg, S.-K., \& Nilsen, H. (2020). Use of spectroscopic techniques for a rapid and non-destructive monitoring of thermal treatments and storage time of sous-vide cooked cod fillets. Sensors (Switzerland), 20(8), 2410. https://doi.org/10.3390/s20082410.

Jaeger, H., Roth, A., Toepfl, S., Holzhauser, T., Engel, K.-H., Knorr, D., Vogel, R. F., Bandick, N., Kulling, S., Heinz, V., \& Steinberg, P. (2016). Opinion on the use of ohmic heating for the treatment of foods. Trends in Food Science \& Technology, 55, 84-97. https://doi. org/10.1016/J.TIFS.2016.07.007.

Kandpal, L. M., Lee, H., Kim, M. S., Mo, C., \& Cho, B. K. (2013). Hyperspectral reflectance imaging technique for visualization of moisture distribution in cooked chicken breast. Sensors (Switzerland), 13(10), 13289-13300. https://doi.org/10.3390/ s131013289.

Kendirci, P., Icier, F., Kor, G., \& Onogur, T. A. (2014). Influence of infrared final cooking on polycyclic aromatic hydrocarbon formation in ohmically pre-cooked beef meatballs. Meat Science, 97(2), 123-129. https://doi.org/10.1016/j.meatsci.2014.01.020.

Kondjoyan, A., Portanguen, S., Duchène, C., Mirade, P. S., \& Gandemer, G. (2018). Predicting the loss of vitamins B3 (niacin) and B6 (pyridoxamine) in beef during cooking. Journal of Food Engineering, 238(June), 44-53. https://doi.org/10.1016/j.jfoodeng. 2018.06.008

Kor, G., \& Icier, F. (2016). Thermal imaging during infrared final cooking of semi-processed cylindrical meat product. Infrared Physics and Technology, 79, 242-251. https://doi.org/10.1016/j. infrared.2016.11.002.

Kubo, M. T., Siguemoto, É. S., Funcia, E. S., Augusto, P. E., Curet, S., Boillereaux, L., Sastry, S. K., \& Gut, J. A. W. (2020). Non-thermal effects of microwave and ohmic processing on microbial and enzyme inactivation: a critical review. Current Opinion in Food Science, 35, 36-48. https://doi.org/10.1016/j.cofs.2020.01.004.

Li, H., \& Sun, D. (2017). Effects of low temperature cooking methods and holding times on selected quality attributes of cooked pork longissimus dorsi. Journal of Food Process Engineering, 40(6), 12585. https://doi.org/10.1111/jfpe.12585.

Li, S., Tang, S., Yan, L., \& Li, R. (2019). Effects of microwave heating on physicochemical properties, microstructure and volatile profiles of yak meat. Journal of Applied Animal Research, 47(1), 262-272. https://doi.org/10.1080/09712119.2019.1624553.

Liu, Y., Sun, D., Cheng, J.-H., \& Han, Z. (2018). Hyperspectral imaging sensing of changes in moisture content and color of beef during microwave heating process. Food Analytical Methods, 11(9), 2472-2484. https://link.springer.com/article/10.1007/s12161-0181234-x.

Luo, J., Taylor, C., Nebl, T., Ng, K., \& Bennett, L. E. (2018). Effects of macro-nutrient, micro-nutrient composition and cooking conditions on in vitro digestibility of meat and aquatic dietary proteins. Food Chemistry, 254, 292-301. https://doi.org/10.1016/J.FOODCHEM. 2018.01.164.

Ma, J., Pu, H., \& Sun, D.-W. (2018). Predicting intramuscular fat content variations in boiled pork muscles by hyperspectral imaging using a novel spectral pre-processing technique. LWT, 94, 119-128. https:// doi.org/10.1016/J.LWT.2018.04.030

Ma, J., Cheng, J. H., Sun, D. W., \& Liu, D. (2019). Mapping changes in sarcoplasmatic and myofibrillar proteins in boiled pork using hyperspectral imaging with spectral processing methods. $L w t$, 110(May), 338-345. https://doi.org/10.1016/j.lwt.2019.04.095.
McGee, H. (2004). Meat. In On food and cooking; the science and lore of the kitchen (pp. 118-178). New York: Scribner.

Mitra, B., Lametsch, R., Akcan, T., \& Ruiz-Carrascal, J. (2018). Pork proteins oxidative modifications under the influence of varied timetemperature thermal treatments: a chemical and redox proteomics assessment. Meat Science, 140, 134-144. https://doi.org/10.1016/J. MEATSCI.2018.03.011.

Miyaoka, R., Ando, M., Harada, R., Osaka, H., Samuel, A. Z., Hosokawa, M., \& Takeyama, H. (2020). Rapid inspection method for investigating the heat processing conditions employed for chicken meat using Raman spectroscopy. Journal of Bioscience and Bioengineering, $x x x(\mathrm{xxx})$. https://doi.org/10.1016/j.jbiosc.2020.01. 002.

O'Farrell, M., Bakke, K. A. H., Tschudi, J., \& Wold, J. P. (2011). Nearinfrared (NIR) interactance system for non-contact monitoring of the temperature profile of baked liver pâté. Applied Spectroscopy, 65(12), 1372-1379. https://doi.org/10.1366/11-06277.

Pathare, P. B., \& Paul, A. (2016). Quality and energy evaluation in meat cooking. Food Engineering Reviews, 8(4), 435-447. https://doi.org/ 10.1007/s12393-016-9143-5.

Perez-Palacios, T., Caballero, D., González-Mohíno, A., Mir-Bel, J., \& Antequera, T. (2019). Near infrared reflectance spectroscopy to analyse texture related characteristics of sous vide pork loin. Journal of Food Engineering, 263(February), 417-423. https://doi.org/10. 1016/j.jfoodeng.2019.07.028.

Porep, J. U., Kammerer, D. R., \& Carle, R. (2015). On-line application of near infrared (NIR) spectroscopy in food production. Trends in Food Science \& Technology, 46(2), 211-230. https://doi.org/10.1016/J. TIFS.2015.10.00

Rahimi, D., Kashaninejad, M., Ziaiifar, A. M., \& Mahoonak, A. S. (2018). Effect of infrared final cooking on some physico-chemical and engineering properties of partially fried chicken nugget. Innovative Food Science and Emerging Technologies, 47(January), 1-8. https://doi.org/10.1016/j.ifset.2018.01.004.

Rakotondramavo, A., Rabesona, H., Brou, C., de Lamballerie, M., \& Pottier, L. (2019). Ham processing: effects of tumbling, cooking and high pressure on proteins. European Food Research and Technology, 245(2), 273-284. https://doi.org/10.1007/s00217-0183159-4.

Sahar, A., Boubellouta, T., Portanguen, S., Kondjoyan, A., \& Dufour, É. (2009). Synchronous front-face fluorescence spectroscopy coupled with parallel factors (PARAFAC) analysis to study the effects of cooking time on meat. Journal of Food Science, 74(9), E534E539. https://doi.org/10.1111/j.1750-3841.2009.01365.x.

Sahar, A, Portanguen, S., \& Dufour, A. K. É. (2010). Potential of synchronous fuorescence spectroscopy coupled with chemometrics to determine the heterocyclic aromatic amines in grilled meat. European Food Research and Technology, 803-812. https://doi. org/10.1007/s00217-010-1323-6

Sahar, A., Rahman, U. u., Kondjoyan, A., Portanguen, S., \& Dufour, E. (2016). Monitoring of thermal changes in meat by synchronous fluorescence spectroscopy. Journal of Food Engineering, 168, 160-165. https://doi.org/10.1016/J.JFOODENG.2015.07.038.

Sobral, M. M. C., Cunha, S. C., Faria, M. A., \& Ferreira, I. M. P. L. V. O. (2018). Domestic cooking of muscle foods: impact on composition of nutrients and contaminants. Comprehensive Reviews in Food Science and Food Safety, 17(2), 309-333. https://doi.org/10.1111/ 1541-4337.12327.

Sun, D.-W. (Ed.). (2012). Thermal food processing. New technologies and quality issues. Boca Raton, FL: CRC Press Taylor \& Francis Group.

Sun, H. X., Huang, F., Ding, Z. J., Zhang, C. J., Zhang, L., \& Zhang, H. (2017). Low-field nuclear magnetic resonance analysis of the effects of heating temperature and time on braised beef. International Journal of Food Science and Technology, 52(5), 1193-1202. https://doi.org/10.1111/ijfs.13384. 
Taşkıran, M., Olum, E., \& Candoğan, K. (2020). Changes in chicken meat proteins during microwave and electric oven cooking. Journal of Food Processing and Preservation, 44(2), 1-8. https:// doi.org/10.1111/jfpp.14324.

Tian, X., Wu, W., Yu, Q., Hou, M., Jia, F., Li, X., \& Dai, R. (2016). Quality and proteome changes of beef M.longissimus dorsi cooked using a water bath and ohmic heating process. Innovative Food Science \& Emerging Technologies, 34, 259-266. https://doi.org/ 10.1016/J.IFSET.2016.02.013

Tian, X., Shao, L., Yu, Q., Li, W. S. X., \& Dai, R. (2020). Comparative analysis of quality uniformity of ohmic and water bath heating treated pork batter with different fat content. Journal of Food Processing and Preservation, (January), 1-11. https://doi.org/10.1111/jfpp. 14377.

Tschudi, J., O'Farrell, M., \& Hestnes Bakke, K. A. (2018). Inline Spectroscopy: From Concept to Function. Applied Spectroscopy, 72(9), 1298-1309. https://doi.org/10.1177/0003702818788374

Wold, J. P. (2016). On-line and non-destructive measurement of core temperature in heat treated fish cakes by NIR hyperspectral imaging. Innovative Food Science and Emerging Technologies, 33, 431-437. https://doi.org/10.1016/j.ifset.2015.12.012.

Wold, J. P., O'Farrell, M., Tschudi, J., Eskildsen, C. E., Andersen, P. V., \& Ottestad, S. (2020). In-line and non-destructive monitoring of core temperature in sausages during industrial heat treatment by NIR interaction spectroscopy. Journal of Food Engineering, 277(January), 109921. https://doi.org/10.1016/J.JFOODENG. 2020.109921.

Xiong, Z., Sun, D.-W., Zeng, X.-A., \& Xie, A. (2014). Recent developments of hyperspectral imaging systems and their applications in detecting quality attributes of red meats: a review. Journal of Food Engineering, 132, 1-13. https://doi.org/10.1016/J.JFOODENG. 2014.02.004.

Xu, X. L., Han, M. Y., Fei, Y., \& Zhou, G. H. (2011). Raman spectroscopic study of heat-induced gelation of pork myofibrillar proteins and its relationship with textural characteristic. Meat Science, 87(3), 159-164. https://doi.org/10.1016/j.meatsci.2010.10.001.

Yang, H., Zhang, W., Li, T., Zheng, H., Khan, M. A., Xu, X., Sun, J., \& Zhou, G. (2016). Effect of protein structure on water and fat distribution during meat gelling. Food Chemistry, 204, 239-245. https:// doi.org/10.1016/j.foodchem.2016.01.053
Yang, T., Zhao, B., \& He, L. (2019). Raman instruments for food quality evaluation. Evaluation Technologies for Food Quality, 119-143. https://doi.org/10.1016/B978-0-12-814217-2.00008-1.

Yildiz Turp, G., Icier, F., \& Kor, G. (2016). Influence of infrared final cooking on color, texture and cooking characteristics of ohmically pre-cooked meatball. Meat Science, 114, 46-53. https://doi.org/10. 1016/j.meatsci.2015.12.006.

Yu, T. Y., Morton, J. D., Clerens, S., \& Dyer, J. M. (2015). Proteomic investigation of protein profile changes and amino acid residue level modification in cooked lamb meat: the effect of boiling. Journal of Agricultural and Food Chemistry, 63(41), 9112-9123. https://doi. org/10.1021/acs.jafc.5b03324.

Yu, T. Y., Morton, J. D., Clerens, S., \& Dyer, J. M. (2016). Proteomic investigation of protein profile changes and amino acid residue-level modification in cooked lamb longissimus thoracis et lumborum: the effect of roasting. Meat Science, 119, 80-88. https://doi.org/10. 1016/j.meatsci.2016.04.024.

Yu, T. Y., Morton, J. D., Clerens, S., \& Dyer, J. M. (2017). Cookinginduced protein modifications in meat. Comprehensive Reviews in Food Science and Food Safety, 16(1), 141-159. https://doi.org/10. 1111/1541-4337.12243.

Zhang, L., Du, H., Zhang, P., Kong, B., \& Liu, Q. (2020b). Heterocyclic aromatic amine concentrations and quality characteristics of traditional smoked and roasted poultry products on the northern Chinese market. Food and Chemical Toxicology, 135(September 2019), 110931. https://doi.org/10.1016/j.fct.2019.110931.

Zhang, L., Lan, R., Zhang, B., Erdogdu, F., \& Wang, S. (2020a). A comprehensive review on recent developments of radio frequency treatment for pasteurizing agricultural products. Critical Reviews in Food Science and Nutrition, 1-15. https://doi.org/10.1080/ 10408398.2020.1733929.

Zhu, Z., Huang, M., Cheng, Y., Khan, I. A., \& Huang, J. (2020). A comprehensive review of $\mathrm{N} \varepsilon$-carboxymethyllysine and $\mathrm{N} \varepsilon$ carboxyethyllysine in thermal processed meat products. Trends in Food Science and Technology, 98(September 2019), 30-40. https:// doi.org/10.1016/j.tifs.2020.01.021.

Publisher's Note Springer Nature remains neutral with regard to jurisdictional claims in published maps and institutional affiliations. 